(c) Elsevier/INRA

\title{
Goat's milk in Europe
}

\section{Current research on goat's milk in Spain}

\author{
M Ramos 1, M Juarez 2 \\ 1 Instituto de Fermentaciones Industriales (CSIC), Juan de la Cierva 3, 28006 Madrid; \\ 2 Instituto del Frio (CSIC), Ciudad Universitaria, 28040 Madrid, Spain
}

\begin{abstract}
Summary - The Spanish caprine sector, including the production of milk, goat populations, breeds and size of farms has been reviewed. The use of goat's milk, the types and manufacturing processes of the most characteristic Spanish cheeses have been examined. This study also reviews the current status of research on goat's milk and cheese: hygiene and quality, control, detection of mixtures of milk from different species, cheese technology and research projects currently underway.
\end{abstract}

goat's milk / production / Spanish cheeses / research project

Résumé - Recherche sur le lait de chèvre en Espagne. La filière caprine espagnole, la production du lait et les races de chèvres, la taille des troupeaux sont présentées. Sont également décrites les utilisations du lait de chèvre, les types et les technologies de fabrication des fromages les plus caractéristiques. Les principaux thèmes de recherches en cours sur le lait et le fromage de chèvre : qualité hygiénique, détection de mélanges de laits appartenant à différentes espèces, technologie du fromage sont évoqués.

lait de chèvre / production / fromages espagnols / recherche

\section{INTRODUCTION}

In 1991, Spanish goat stock numbered 2972 thousand heads, nearly $50 \%$ of which were milk-bearing females over $1 \mathrm{yr}$ old. Small herds are still prevalent: $46 \%$ of the 34000 herds number $<30$ heads, although another $22 \%$ number $>100$ (Rodriguez Rebollo, 1992). Unlike Spain's sheep flocks, goats are bred mainly for milk production, $62 \%$ of total output being from the Murciana-Granadina, Malagueña and Serrano breeds largely located in Andalucia and Castilla-La Mancha. Fourteen percent of the total is produced by the $\mathrm{Ca}$ narias breed in the Canary Islands.

Milk output has increased considerably over the last $10 \mathrm{yr}$, rising from 290 million I in 1980 to 473 million I in 1990 . Of the total milk output, $13 \%$ is consumed locally as liquid milk and the rest is used in cheese-making. Of this, $11 \%$ is manufactured by hand. Traditionally, Spanish goat's milk cheese production has been a 
craft rather than an industrial process, and as a result there are many different local varieties, with fresh cheeses constituting the bulk of production. Other problems facing the industry are the seasonal character of production, peaking in spring, and the high cost of collection due to the location of the herds in remote mountain regions.

\section{SPANISH GOAT'S MILK CHEESES}

The Catalogue of Spanish Cheeses published by the Ministry of Agriculture (1991) lists 25 pure goat's milk cheeses, and 21 cheeses made from mixtures of goat's milk and cow's and/or ewe's milk. This means that of the total of 81 cheeses shown on the cheese map $57 \%$ are manufactured from goat's milk.

A substantial proportion of Spanish goat milk production is used to make cheeses based on a mixture of goat's, cow's and ewe's milks. Of these, special mention should be made of the lberico cheese, which has a standardized composition and characteristics and requires a minimum of $25 \%$ of each of the milks from the 3 species.

Most cheeses can be classified into one of the following groups: fresh cheeses, soft-curd cheeses, semi-hard cheeses and hard pressed-curd cheeses. Fresh cheeses are soft and either unfermented or subjected to natural lactic fermentation, and are marketed fresh or after 15-20 d of ripening. The most popular semi-hard, lightly pressed-curd cheeses are Huelva, Valdeteja and Majorero cheeses, which are marketed after 1 month or 1 and a half months, although some are kept in oil for a much longer period. Artisanal Majorero cheese is made from raw goat's milk without the addition of starter cultures using rennet extracted from macerated, sun- dried kid stomachs. Coagulation takes place at an ambient temperature of up to $40-45^{\circ} \mathrm{C}$ for periods ranging from $15 \mathrm{~min}$ to $2 \mathrm{~h}$. The cheeses are moulded in a variety of ways and salted, often being drysalted with $\mathrm{NaCl}$.

Washed-curd cheese is another successful product manufactured from goat's milk. The aim was to obtain a mild soft cheese for consumption over longer ripening periods than those for fresh cheeses. The basic difference between washed-curd cheeses and semi-hard cheeses is that the curd is washed with a sodium chloride solution to remove part of the residual lactose, thereby reducing acidity. The cheeses are brine-salted and matured for 1-2 months under conventional ripening conditions $\left(10-12^{\circ} \mathrm{C} ; 85 \%\right.$ relative humidity) (Yubero, 1985).

More recently, soft cheeses with surface flora have begun to be marketed in Spain. Their characteristics are similar to those of French goat's milk cheeses. They are made from pasteurized milk and aromatizing and acidifying mesophilic starters. Coagulation temperature is $20-22^{\circ} \mathrm{C}$, and $\mathrm{co}$ agulation time $18-20 \mathrm{~h}$. The cheeses are brine-salted, dusted with Penicillium candidum or Geotricum candidum spores, and ripened for 15-20 d. After ripening they are stored at $0-4^{\circ} \mathrm{C}$ until sale. The cheeses are cylindrical in shape and of variable height.

\section{CURRENT STATUS OF RESEARCH IN SPAIN}

\section{Milk: hygiene and quality}

A number of studies have been conducted on hygiene and quality of raw milk to evaluate lactoperoxidase (LP) and thiocyanate content through lactation in goat's milk in 2 economically important Spanish breeds: 
Verata and Murciana-Granadina (Zapico et al, 1991). Activation of the LP system might be a useful means of preserving raw milk at ambient temperatures and of improving its bacteriological quality at refrigeration temperatures by addition of low levels of thiocyanate and hydrogen peroxide, as LP concentration in goat's milk would not be a limiting factor. In a more recent study on the activity of goat's milk LP system on Listeria monocytogenes, the same authors (Zapico et al, 1992) found bacterial activity against $3 L$ monocytogenes strains at $4^{\circ} \mathrm{C}$. The bacterial activity of the LP system in goat's milk persisted for $8 \mathrm{~d}$ at $4^{\circ} \mathrm{C}$ and for $5 \mathrm{~d}$ at $8^{\circ} \mathrm{C}$.

The composition of milk from the most prevalent Spanish breeds has also been studied by a number of groups. Table I shows the range reported for the major components in milk from the MurcianaGranadina and Canaria breeds. In some breeds, characterization has been more comprehensive, including nitrogenated fractions, proportion of casein fractions, mineral elements and fatty-acid composition of the fats (Martin-Hernandez et al, 1988).
Another aspect currently being investigated is the study of genetic variants of goat's milk cheese from autochthonous breeds. Rabasco et al (1993a, b) employing high-resolution electrophoretic techniques including 2-dimensional electrophoresis to examine casein variants in milk from Verata goats, have reported qualitative and quantitative polymorphism in the $\alpha_{s 1}$-casein fraction. Genetic polymorphism of milk proteins (mainly $\alpha_{s 1}$-casein) has been studied in the Spanish breeds Murciano-Granadina, Malagueña, Payoya and Canaria (Jordana et al, 1991); work is in progress to determine the correlation between this polymorphism and production traits in these breeds. Furthermore, molecular characterization of goat's milk $\beta$ lactoglobulin and $\alpha_{\mathrm{s} 1}$-casein has recently been performed (Coll et al, 1993 ; Folch et al, 1993), and gene constructs carrying regulatory sequences of these genes have been assayed in transgenic mice. The purpose of this study is the obtention of transgenic goats with overexpression of proteins in the mammary gland, thereby providing the possibility for manipulation of milk composition.

Table I. Characteristics of composition of goat's milk from the Murciana-Granadina and Canaria breeds.

Composition du lait de chèvre des races Murciana-Granadina et Canaria.

Variable

Breed

Murciana-Granadina

(Juarez et al, 1991)
Canaria

(Fresno et al, 1992)
Fat (\%)

Total solids (\%)

Proteins (\%)

Casein (\%)

Calcium $(g / l)$

Phosphorus ( $g / l)$

Ash (\%)
$4.5-6.6$
$13.2-15.7$
$3.5-3.6$
$2.7-2.8$
$1.51-1.73$
$0.91-0.95$
$0.82-0.89$

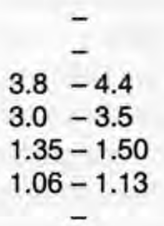


Diaz Carrillo et al (1992), have used near infra-red spectra (NIR) for quantitative determination of casein fractions in goat's milk and have correlated the different contents with milk yield. Genetic and non-genetic sources of variation in yield and composition of milk in Verata goats has been studied by Rabasco et al (1993a, b). Ratios of cheese yield to coagulation parameters determined by thrombelastograph have been studied by Perez et al (1991). Murciana-Granadina goat's milk presents excellent technological characteristics and optimum cheese yields.

Certain members of our group (LopezFandiño et al, 1993) have conducted a comparative study by HPLC on caseinomacropeptides (CMP) from cow's, ewe's and goat's milk. The differences detected in chromatographic behavior between CMP from cow's, ewe's and goat's milk are useful in the detection by RP-HPLC of fraudulent addition of whey solids to milk.

\section{Detection of mixtures of milk from different species}

Another subject which has been studied by a number of research groups is the detection of mixtures of cow's, ewe's and goat's milk. Polyacrylamide-gel electrophoresis (PAGE), isoelectric focusing (IEF) and chromatographic (HPLC-RP) methods have been developed which can be applied to the whey protein fraction to identify the milk from each species. Amounts of $1-2 \%$ cow's or goat's milk have been detected in ewe's milk cheeses (Amigo et al, 1989 ; de Frutos et al, 1992). Amigo et al (1991) have studied the influence of a number of technological parameters (type of coagulant, pressing, ripening time and heat treatment) in electrophoretic detection of cow's milk in ewe's milk cheeses. Whey proteins are less sen- sitive to proteolysis than caseins, but are more sensitive to heating. The same group (Amigo et al, 1992) compared an immunological and an electrophoretic method (IEF and PAGE) for the determination of goat's and cow's milk in the "Serra da Estrela" cheese. Adulteration of this type of cheese (coagulated by vegetable coagulant) mainly took the form of addition of goat's milk. No significant differences were found in quantitative results via electrophoretis or isoelectric focusing.

Hernandez's group has developed polyclonal antibodies against whey proteins and total caseins in goat's milk. The antibodies developed against whey proteins can be neutralized or purified by immunoadsorption and biotinylated for use in an ELISA sandwich (Garcia et al, 1993) to determine and quantify the presence of goat's milk in ewe's milk. The antibodies developed against goat's milk caseins likewise neutralized or purified by immunoadsorption and biotinylated have been used in an indirect ELISA assay (Rodriguez et al, 1991) to determine the presence of goat's milk in ewe's milk and cheeses.

Calvo's group has developed 2 enzyme immunoassays based on immunodot techniques using antibodies against caseins (Aranda et al, 1988) or immunoglobulins (Calvo et al, 1989) to detect cow's milk in ewe's milk. Recently the same authors (Aranda et al, 1993) have designed an immunodot assay to detect the presence of goat's and/or cow's milk in ewe's milk and ewe's milk cheeses. These methods offer the advantage of high sensitivity and simplicity, and are suitable for use as "field" tests for a large number of samples.

\section{Cheese technology}

The chemical composition of some Spanish goat's milk cheeses has also been 
studied. Juarez et al (1991) and Juarez and Ramos (1992) have reviewed the advances in the manufacture of Spanish goat's milk cheeses. Studies on the microbiology of other Spanish goat's milk cheeses, namely Valdeteja, Gredos, and Acehuche, have been reviewed by Nuñez (1991).

The development of specific starters for the manufacture of semi-hard goat's milk cheeses using autochthonous strains selected from artisanal cheeses is another feature that is of potential interest, since it could be used to produce cheeses with standard characteristics and longer ripening periods. At our laboratory, Requena et al (1992) recently developed a starter culture for manufacturing a semi-hard goat's milk cheese composed of Lactococcus lactis subsp lactis, Lactobacillus casei subsp casei, L plantarum, Leuconostoc mesenteroides subsp dextranicum and $L$ paramesenteroides.

At our laboratory Martín-Hernández et al (1990) studied the effect of freezing on 5 types of goat's milk cheeses (fresh, semihard, washed-curd, soft with surface flora, and Majorero). After brine-salting the cheeses were frozen in a plate freezer at $-40^{\circ} \mathrm{C}$ or in liquid nitrogen vapor at $-80^{\circ} \mathrm{C}$ and then stored at $-20^{\circ} \mathrm{C}$ for 4 months. After thawed, they were then ripened conventionally and analyzed periodically over the ripening period. The overall composition was not affected by freezing. The characteristics of the fat fraction were comparable in the control and frozen batches; however, the level of free fatty acids was significantly higher in the previously frozen soft cheese with surface flora. The most significant variations in the proteolysis index values were recorded in the amino acid nitrogen fraction, which was higher in the previously frozen cheese. Organoleptically only the previously frozen fresh cheese obtained a lower sensory analysis rating than the control cheeses.

\section{Current research projects}

Table II shows the research projects funded by the National Research and Development Plan food technology program over the last $5 \mathrm{yr}$ and the groups involved, including those projects currently underway.

In the detection of cow's milk in mixtures with goat's milk, Hernández et al are currently isolating casein fractions and assessing them for immunogenicity. The most immunogenic fraction is used in the immunization of mice to obtain monoclonal antibodies for use in developing ELISA methods suitable for detection of mixtures. Our laboratory is utilizing capillary electrophoresis and isoelectrofocusing to analyze the $\gamma_{2}$ and para $\kappa$-casein from lbérico cheeses manufactured from cow's, ewe's and goat's milk.

A project currently underway in the framework of the EC's ECLAIR programme has been set up along these lines. The aims of the project are: 1) isolation and characterization of the major lactic acidproducing bacteria in "natural" starters from Greece, Portugal, Spain, France and Italy; and 2) development of new dairy products using strains with unusual flavor profiles. In this project we are working on goat's milk products.

Approval has been recently given to the Agriculture and Agro-Industry programme, a project on the study of lactic bacteria which are not integrated in the starter. Another project, funded by the National Plan and the EC, is being implemented at the Institute for Industrial Fermentations. Its purpose is to study the influence of UHT heat treatment on the chemical composition of goat's milk, and more specifically, the behavior of proteins and carbohydrates during pasteurization and UHT processes.

Guamis' group Autónoma University of Barcelona studies on the effect of treat- 
Table II. National R \& D plan. Food technology program. Funded projects on goat's milk and cheeses (1988-1992).

Plan national de recherche et développement. Programme de technologie alimentaire. Projets subventionnés sur le lait et les fromages de chèvre (1988-1992).

\begin{tabular}{|c|c|c|c|}
\hline Subject & Institution & Researcher & Period \\
\hline $\begin{array}{l}\text { Differentiation of mixtures of cow's, sheep's } \\
\text { and goat's milk via ELISA methodologies }\end{array}$ & $\begin{array}{l}\text { Universidad Complutense de Madrid, } \\
\text { Facultad de Veterinaria }\end{array}$ & PE Hernández & $1988-1991$ \\
\hline $\begin{array}{l}\text { The use of the proteic fraction to differentiate } \\
\text { closely related foods }\end{array}$ & CSIC, Inst de Fermentaciones Industriales & MC Polo & 1988-1991 \\
\hline $\begin{array}{l}\text { Improvement in the technological process of } \\
\text { manufacture of ewe's and goat's cheeses }\end{array}$ & CSIC, Inst de Fermentaciones Industriales & M Ramos & $1988-1991$ \\
\hline $\begin{array}{l}\text { Modifications in proteins and carbohydrate-protein } \\
\text { interactions during thermal treatment, freezing and } \\
\text { storage of dairy products }\end{array}$ & CSIC, Instituto del Frio & M Juárez & $1988-1991$ \\
\hline $\begin{array}{l}\text { Detection of cow's milk in milk mixtures and cheese } \\
\text { via monoclonal antibodies and enzyme-linked } \\
\text { immunosorbent assays (ELISA) }\end{array}$ & $\begin{array}{l}\text { Universidad de Madrid, } \\
\text { Facultad de Veterinaria }\end{array}$ & R Martin & $1991-1994$ \\
\hline $\begin{array}{l}\text { Modifications in protein and carbohydrate-protein } \\
\text { interactions during microwave and continuous flow } \\
\text { heat treatment applied to milk from different species }\end{array}$ & CSIC, Inst de Fermentaciones Industriales & A Olano & $1991-1994$ \\
\hline $\begin{array}{l}\text { Characterization and improvement of lactic } \\
\text { acid bacteria for cheese manufacture }\end{array}$ & CSIC, Instituto del Frio & C Peláez & $1991-1994$ \\
\hline $\begin{array}{l}\text { Factors controlling the growth and toxin production } \\
\text { of cold-tolerant pathogenic microorganisms in } \\
\text { ewe's and goat's milk cheeses }\end{array}$ & $\begin{array}{l}\text { Universidad de León, } \\
\text { Facultad de Veterinaria }\end{array}$ & ML García-López & $1991-1994$ \\
\hline $\begin{array}{l}\text { New criteria for goat selection based upon } \\
\text { milk casein contents and variation }\end{array}$ & $\begin{array}{l}\text { Universidad de Córboda Agrónomos } \\
\text { Escuela Superior de Ingenieros, }\end{array}$ & JM Serradilla & 1992-1995 \\
\hline
\end{tabular}


ment conditions (pressure, time and temperature) on microorganisms, physicochemical and organoleptic properties of goat's and sheep's milk and dairy products are being carried out in the framework of an EC project.

\section{ACKNOWLEDGMENT}

This work has been supported by the Comision Interministerial de Ciencia y Tecnologia, Project ALI-91-0784.

\section{REFERENCES}

Amigo L, Ibañez I, Fernandez C, Santamaría G, Ramos M (1989) Comparison of an electrophoretic and immunological method for the determination of goat and cow milk in cheese. Milchwissenschaft 44, 215-218

Amigo L, Ramos M, Martin-Alvarez PJ, Barbosa $M$ (1991) Effect of technological parameters on electrophoretic detection of cow's milk in ewe's cheeses. J Dairy Sci 74, 1482-1491

Amigo L, Ramos M, Calhau L, Barbosa M (1992) Comparison of electrophoresis, isoelectrofocusing and immunodiffusion in determinations of cow's and goat's milk in Serra da Estrela cheese. Lait 72, 95-101

Aranda P, Oria R, Calvo M (1988) Detection of cow's milk in ewe's milk by immunodotting method. J Dairy Res 35, 383-384

Aranda P, Sánchez L, Pérez MD, Ena JM, Puyol P, Oria R, Calvo M (1993) Rapid immunoenzymatic method for detecting adulteration in ewe's milk. Food Control 4, 101-104

Calvo M, Aranda P, Sanchez L, Perez MD, Ena JM (1989) Metodo inmunoenzimático rapido de detección de la presencia de distinta especie en leche de oveja. Patent No P8902690

Coll A, Folch JM, Sanchez A (1993) Nucleotide sequence of goat $\kappa$-casein cDNA. J Anim Sci (in press)

de Frutos M, Cifuentes A, Amigo L, Ramos M, Diez-Masa JC (1992) Rapid analysis of whey proteins from different animal species by re- versed-phase high performance liquid chromatography. Z Lebensm Inters Forsch 195, 326-331

Diaz-Carrillo E, Muñoz-Serrano A, Serradilla JM, Alonso-Moraga A (1992) Evolution through lactation of protein caseins, fat and lactose contents in three Spanish breeds of goats. 43rd Annu Meet EAAP, Madrid ; abstr 198

Folch JM, Coll A, Sanchez A (1993) Cloning and sequencing of the goat $\beta$-lactoglobulin $c D N A$. $J$ Anim Sci (in press)

Fresno M, Capote J, Darmanin N, Martin P, Ohinea E, Corbella M (1992) Caracterización de los tipos étnicos de la Agrupación caprina canaria. Ind Lact Esp 33-37

García T, Martín R, Morales P, González I, Sanz B, Hernández PE (1993) Sandwich ELISA for detection of caprine milk in ovine milk. Milchwissenchaft (in press)

Jordana J, Sánchez A, Jansá $M$, Mahé MF Grosclaude F (1991) Estudio comparativo de las razas caprina españolas en relación a las variantes de la caseine $\alpha_{s}$. Inf Tec Econ Agrar 11, 598-600

Juarez M, Ramos M (1992) Advances in the manufacture of goat's cheeses. In: Vth Int Conf Goats. New Delhi, vol II, part II, 394398

Juarez M, Ramos M, Martín Hernández $C$ (1991) Quesos Españoles de Leche de Cabra. FESLAC, Madrid

Lopez-Fandiño R, Acedo I, Ramos M (1993) Comparative study by HPLC of caseinomacropeptides from cow's, ewe's and goat's milk. $J$ Dairy Res 60, 117-121

Martin-Hernández $C$, Juarez $M$, Ramos $M$, Martin-Alvarez PJ (1988) Composición de la leche de cabra de razas Murciana y Granadina. Anal Bromatol 40, 237-248

Martín-Hernández $C$, Juarez $M$, Ramos $M$, Martin-Alvarez PJ (1990) Effects of freezing and frozen storage on the physicochemical and sensory characteristics of four types of goat's cheese. $Z$ Lebensm Unters Forsch $190,325-330$

Ministerio de Agricultura (1991) Catálogo de Quesos de España 1991. Ministerio de Agricultura Pesca y Alimentación, Spain

Nuñez M (1991) Microbiología de quesos españoles. In: Nuevos Métodos para Productos Lácteos. Consejería de Agricultura, Gan- 
aderia y Montes, Venus Astes Gráficas, SA, La Coruña, Spain

Perez S, Goicoechea A, Romero C, Falagán A, Gonzalez MC (1991) Technological aptitude and cheese yield on goat's milk. Chem Mikrobiol Technol Lebensm 13, 83-88

Rabasco A, Padilla JA, Chianese L (1993a) Variabilidad de las fracciones caseínicas de la leche en cabras de raza Verata. Arch Zootec (in press)

Rabasco A, Serradilla JM, Padilla JA, Serrano A (1993b) Genetic and non genetic sources of variation in yield and composition of milk in Verata goats. Small Ruminant Res 11 (in press)

Requena T, De la Fuente MA, Fernández de Palencia P, Juarez M, Pelaez C (1992) Evaluation of a specific starter for the production of semi-hard goat's cheese. Lait 72, 437-448
Rodriguez-Rebollo M (1992) Microbios y fronteras a la luz del Mercado único de la leche, Ind Lact Esp Oct, 33-63

Rodriguez ER, Martín R, García T, Azcona Jl, Sanz B, Hernández PE (1991) Indirect ELISA for detection of goat's milk in ewe's milk and cheese. Int J Food Sci Technol 26, 457-465

Yubero A (1985) Situación actual de la producción de quesos de cabra y su futuro. Rev Esp Leche Nov-Dec, 17-24

Zapico P, Gaya P, Medina M, Nuñez M (1992) Activity of goat's milk lactoperoxidase system on Listeria monocytogenes. In: 11th Int Symp Problems of Listeriosis. Copenhagen, abstr 342-343

Zapico P, Gaya P, De la Paz M, Nuñez M, Medina M (1991) Influence of breed, animal and days of lactation on lactoperoxidase. J Dairy Sci $74,783-787$ 